\title{
I.Я. Гушул
}

Кафедра онкології та радіологї (зав. - проф. О.І. Іващук) ВДНЗ Украӥни “Буковинський державний медичний університет”, м. Чернівиі.

\section{МІКРОБІОЛОГІЧНІ ОСОБЛИВОСТІ ПЕРЕБІГУ ГОСТРОГО ПОШИРЕНОГО ПЕРИТОНІТУ НА ТЛІ РАКУ ТОВСТОЇ КИШКИ}

\begin{abstract}
Резюме. У статті представлені результати дослідження якісного та кількісного складу мікрофлори перитонеального ексудату після моделювання гострого поширеного перитоніту на тлі заздалегідь створеного раку товстої кишки. Встановлено, що утворення гострого поширеного перитоніту на тлі раку товстої кишки впродовж 48 годин характеризується вірогідним збільшенням кількості висіяних штамів K. pneumoniae, мікроорганізмів роду Proteus (P. vulgaris, P. mirabilis, P. morganii), дріжджоподібних грибів роду Candida, появою росту S. aureus, а також зростанням популяційного рівня E. coli, K. pneumoniae, мікроорганізмів роду Proteus та Streptococcus, дріжджоподібних грибів роду Candida. Це необхідно враховувати при виборі частоти санацій черевної порожнини та методів ії проведення.

Ключові слова: гострий поширений перитоніт, рак товстої кишки, перитонеальний ексудат.
\end{abstract}

Гострий поширений перитоніт (ГПП) є одним із найбільш тяжких ускладнень багатьох захворювань органів черевної порожнини. Незважаючи на значний розвиток сучасної хірургії, ГПП все ще продовжує залишатися досить частою причиною високої летальності, яка досягає 40-85\% [1,2].

Нерідко у хірургічній практиці трапляється ГПП, джерелом якого є злоякісне новоутворення товстої кишки (ТК). Перитоніт, який виник на тлі вже існуючих патологічних змін, спричинених власне раковою хворобою, має ряд патогенетичних особливостей, які значно ускладнюють його перебіг та призводять до незадовільних результатів лікування $[1,3,4]$.

Складність цієї проблеми зумовлена відсутністю об'єктивних критеріїв у виборі обсягу оперативного втручання при ліквідації джерела перитоніту, встановленні показань та виборі методу санації черевної порожнини $[4,5]$.

Експериментальне вивчення мікробіологічних особливостей перебігу ГПП на тлі злоякісного новоутворення ТК дасть змогу більш ефективно проводити лікування хворих на дане захворювання.

Мета дослідження: дослідити в експерименті якісний та кількісний склад мікрофлори перитонеального ексудату після моделювання ГПП на тлі попередньо створеного раку ТК.

Матеріал і методи. Експеримент виконано на 28 статевозрілих нелінійних щурах середнього віку обох статей, масою не менше 180 г, яким змодельовано ГПП иляхом інтраперитонеального введення 30\% калової суспензії в кількості 1,0 мл на 100 г маси тварини [6].

Усі дослідні тварини були розподілені на дві групи - порівняння та основну. Основну групу становили 16 тварин, яким за два тижні до моделювання ГПП прищеплено пухлину Герена у ТК, згідно із запропонованою нами методикою [7]. Групу порівняння становили 12 тварин без раку $T K$.

Забір біологічного матеріалу проводили через 24 та 48 години після моделювання ГПП, під загальним внутрішньом'язовим знеболенням (розчин хлоралгідрату 200-250 мг/кг) з дотриманням правил асептики. Після виконання лапаротоміі проводили бактеріологічне дослідження перитонеального ексудату.

Хірургічні втручання виконано в умовах віварію Буковинського державного медичного університету відповідно до національних вимог "Загальних етичних принципів експериментів на тваринах" (Україна, 2011), які узгоджені з положенням "Свропейської конвениії про захист хребетних тварин, що використовуються для експериментів та інших наукових иілей” (Страсбург, 1985).

Евтаназію щурів здійснювали згідно з етичними стандартами та діючими рекомендаціями, у стані глибокого наркозу, шляхом уведення надлишкової кількості наркотичного препарату, згідно із законом України № 3447-1 від 21.02.2006 p. 
"Про захист тварин від жорстокого поводження”.

Для якісної $і$ кількісної оцінки аеробних та факультативно-анаеробних збудників проводили посіви перитонеального ексудату на середовище Ендо, тіогліколеве середовище, жовтковий агар, анаеробний кров'яний агар та культивували при температурі 37оС упродовж семи діб. Для біохімічної ідентифікації грамнегативної флори використовували тест-системи фірми “Біомерн” на приладі "Міпі Арі" (Франиія). 3 метою визначення росту патогенних грибів використовували середовище Сабуро.

Після інкубачії підраховували кількість колонієутворювальних одиниць (КУО), виявлених у досліджуваному матеріалі, щзо подавали в десятинних логарифмах (lg КУО). Вивчали видовий склад мікроорганізмів, їх популячіииний рівень, коефіцієнт постійності (С\%), частоту виявлення виду (Pi), коефіuієнт значущзості (K3), коефіuієнт кількісного домінування (ККД).

Статистичний аналіз отриманих результатів проводили з використанням електронних таблииь Microsoft Excel ma пакета програм статистичної обробки РАST. Для перевірки вірогідності розподілу даних у вибірках застосовували критеріï Shapiro-Wilk. Розбіжності між групами досліджень визначали за допомогою критеріїв Mann-Whithey. Результат вважали вірогідним, якщзо коефіuієнт вірогідності був $\leq 0,05$, щзо є загальноприйнятим у медико-біологічних дослідженнях.

Результати дослідження та їх обговорення. При посіві ексудату черевної порожнини у всіх без винятку тварин встановлено ріст культур Escherichia coli (E. coli), Klebsiella pneumoniae (K. pneumoniae) мікроорганізмів роду Proteus (P. vulgaris, P. mirabilis, P. morganii), мікроорганізмів роду Streptococcus та дріжджоподібних грибів роду Candida. Також в основній групі тварин у п’яти випадках мав місце Staphylococcus aureus (S. aureus).

Аналізуючи результати дослідження видового складу перитонеального ексудату впродовж всього терміну виявлення, які представлені в таблиці 1, слід відмітити найбільш високий коефіцієнт постійності та частоту виявлення Escherichia coli (E. coli), яка переважає у всіх дослідних групах тварин. У групі порівняння коефіцієнт постійності, а також частота виявлення K. pneumoniae та мікроорганізмів роду Proteus майже однакові, проте в основній групі при останніх переважає.

На 48-му годину спостереження кількість висіяних штамів К. pneumoniae невірогідно зростає, проте в основній групі їх кількість у 1,71 раза $(\mathrm{p}<0,05)$ вища, ніж у групі порівняння. В обох дослідних групах відзначається зростання кількості висіяних штамів мікроорганізмів роду Proteus на 48-му годину спостереження, із вірогідною різницею показників в основній групі. У дані терміни дослідження кількість висіяних штамів мікроорганізмів роду Proteus у тварин основної групи в $2,17(\mathrm{p}<0,05)$ рази вища проти групи порівняння. Кількість висіяних штамів мікроорганізмів роду Streptococcus на 48-му годину спостереження в основній групі тварин вища, проте ця різниця $\epsilon$ невірогідною. На 48-му годину дослідження кількість висіяних штамів дріжджоподібних грибів роду Candida в основній групі тварин у 3,0 рази $(\mathrm{p}<0,05)$ вища ніж у групі порівняння.

Наведені в таблиці 2 результати дослідження популяційного рівня мікроорганізмів перитонеального ексудату свідчать про зростання кількості колоній E. coli на 48-му год спостереження, проте ця динаміка вірогідна тільки у тварин основної групи. Також, на 48-му годину спостереження, у тварин основної групи популяційний рівень Е. coli вірогідно вищий, проти показників групи порівняння у відповідні терміни дослідження.

Популяційний рівень К. pneumoniae основної групи вірогідно перевищує групу порівняння впродовж всього терміну дослідження, із вірогідною динамікою росту на 48-му годину спостереження.

Кількість колоній мікроорганізмів роду Proteus основної групи впродовж всього терміну дослідження вірогідно вищий ніж у групі порівняння. Динаміка росту кількості колоній мікроорганізмів роду Proteus на 48-му годину є недостовірною в обох дослідних групах.

На 48-му годину спостереження відзначається вірогідне зростання популяційного рівня мікроорганізмів роду Streptococcus в основній групі тварин, із вірогідним переважанням показників проти групи порівняння у відповідні терміни.

В основній групі тварин кількість колоній дріжджоподібних грибів роду Candida вірогідно перевищує показники групи порівняння.

Важливим, з точки зору характеристики мікробного співтовариства, є визначення коефіцієнту кількісного домінування (ККД) кожного виду мікроорганізмів перитонеального ексудату (табл. 3).

Домінуючим мікроорганізмом, відповідно до визначеного ККД, у тварин обох дослідних груп впродовж усього терміну дослідження $є$ E. coli. Також у тварин обох груп ККД К. pneumoniae $\epsilon$ вищим за мікроорганізми роду Proteus, проте в основній групі ці показники майже рівні. 
Таблиия 1

Видовий склад мікрофлори перитонеального ексудату після моделювання гострого поширеного перитоніту на тлі злоякісного новоутворення товстої кишки, у різні терміни спостереження,

абс., \%

\begin{tabular}{|c|c|c|c|c|c|c|c|}
\hline \multirow{3}{*}{$\begin{array}{c}\text { Група } \\
\text { тварин }\end{array}$} & \multirow{3}{*}{ Мікроорганізми } & \multicolumn{6}{|c|}{ Термін після моделювання ГПП, година } \\
\hline & & \multicolumn{3}{|c|}{24} & \multicolumn{3}{|c|}{48} \\
\hline & & $\mathrm{s}$ & $\mathrm{C} \%$ & $\mathrm{Pi}$ & $\mathrm{s}$ & $\mathrm{C} \%$ & $\mathrm{Pi}$ \\
\hline \multirow{5}{*}{ 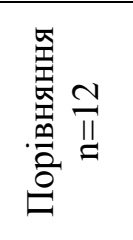 } & E. coli & 12 & 100 & 0,6 & 12 & 100 & 0,38 \\
\hline & K. pneumoniae & 4 & 33,3 & 0,2 & 7 & 58,3 & 0,22 \\
\hline & м/о роду Proteus & 4 & 33,3 & 0,2 & 6 & 50 & 0,19 \\
\hline & м/о роду Streptococcus & - & - & - & 3 & 25 & 0,1 \\
\hline & Др. гриби роду Candida & - & - & - & 3 & 25 & 0,1 \\
\hline \multirow{6}{*}{ 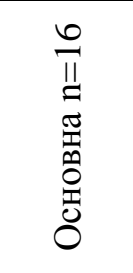 } & E. coli & 16 & 100 & 0,46 & 16 & 100 & 0,25 \\
\hline & K. pneumoniae & 7 & 43,8 & 0,2 & 12 & 75 & 0,19 \\
\hline & м/о роду Proteus & 8 & 50 & 0,23 & 13 & 81,3 & 0,21 \\
\hline & м/о роду Streptococcus & 4 & 25 & 0,11 & 8 & 50 & 0,13 \\
\hline & S. aureus & - & - & - & 5 & 31,3 & 0,08 \\
\hline & Др. гриби роду Candida & - & - & - & 9 & 56,3 & 0,14 \\
\hline
\end{tabular}

Примітки:

1. n - кількість спостережень; 2. м/о - мікроорганізми; 3. s - кількість висіяних штамів; 4. С\% - коефіціснт постійності; 5. Рі - частота виявлення виду

Таблиия 2

Популяційний рівень мікрофлори перитонеального ексудату після моделювання гострого поширеного перитоніту на тлі злоякісного новоутворення товстої кишки, у різні терміни спостереження $(\mathrm{M} \pm \mathrm{m}), \lg \mathrm{KУO} / \mathrm{cm}^{3}$

\begin{tabular}{|c|c|c|}
\hline \multirow{2}{*}{$\begin{array}{c}\text { Дослідна } \\
\text { група тварин } \\
\end{array}$} & \multicolumn{2}{|c|}{ Термін після моделювання ГПП, год } \\
\hline & 24 & 48 \\
\hline \multirow{5}{*}{$\begin{array}{l}\text { Порівняння } \\
\mathrm{n}=12\end{array}$} & $\begin{array}{l}\text { E. coli } \mathrm{s}=12 \\
4,16 \pm 0,154\end{array}$ & $\begin{array}{c}\text { E. coli } \mathrm{s}=12 \\
4,83 \pm 0,286 \mathrm{p}_{1}>0,05\end{array}$ \\
\hline & $\begin{array}{c}\text { K. pneumoniae } s=4 \\
3,28 \pm 0,215\end{array}$ & $\begin{array}{l}\text { K. pneumoniae } s=7 \\
3,82 \pm 0,198 p_{1}>0,05\end{array}$ \\
\hline & $\begin{array}{c}\text { м/o роду Proteus s=4 } \\
2,73 \pm 0,155\end{array}$ & $\begin{array}{c}\text { м/o pоду Proteus s }=6 \\
3,21 \pm 0,156 \mathrm{p}_{1}>0,05\end{array}$ \\
\hline & - & $\begin{array}{c}\text { м/о роду Streptococcus s=3 } \\
3,04 \pm 0,153\end{array}$ \\
\hline & - & $\begin{array}{c}\text { Др. гриби роду Candida s=3 } \\
2,75 \pm 0,151\end{array}$ \\
\hline \multirow{6}{*}{$\begin{array}{l}\text { Основна } \\
\mathrm{n}=16\end{array}$} & $\begin{array}{c}\text { E. coli } s=16 \\
4,76 \pm 0,241 \mathrm{p}>0,05\end{array}$ & $\begin{array}{c}\text { E. coli } s=16 \\
5,66 \pm 0,263 p<0,05 ; p_{1}<0,05\end{array}$ \\
\hline & $\begin{array}{l}\text { K. pneumoniae } s=7 \\
3,88 \pm 0,122 \text { p }<0,05\end{array}$ & $\begin{array}{c}\text { K. pneumoniae } s=12 \\
4,41 \pm 0,17 \mathrm{p}<0,05 ; \mathrm{p}_{1}<0,05\end{array}$ \\
\hline & $\begin{array}{c}\text { м/о роду Proteus } \mathrm{s}=8 \\
3,43 \pm 0,144 \mathrm{p}<0,05\end{array}$ & $\begin{array}{c}\text { м/o роду Proteus } \mathrm{s}=13 \\
3,91 \pm 0,225 \mathrm{p}<0,05 ; \mathrm{p}_{1}>0,05\end{array}$ \\
\hline & $\begin{array}{c}\text { м/о роду Streptococcus } \\
2,92 \pm 0,151 \mathrm{~s}=4\end{array}$ & $\begin{array}{l}\text { м/о роду Streptococcus } s=8 \\
3,65 \pm 0,147 \mathrm{p}<0,05 ; \mathrm{p}_{1}<0,01\end{array}$ \\
\hline & - & $\begin{array}{c}\text { S. aureus s }=5 \\
3,12 \pm 0,149\end{array}$ \\
\hline & - & $\begin{array}{c}\text { Др. гриби роду Candida s }=9 \\
3,48 \pm 0,175 \mathrm{p}<0,05\end{array}$ \\
\hline
\end{tabular}

Примітки:

1. n - кількість спостережень; 2. м/о - мікроорганізми; 3. s - кількість висіяних штамів; 4. p - різниця показників між обома дослідними групами; 5. p $_{1}$ - різниця показників проти 24-ї години спостереження 
Таблиия 3

Коефіціснти значущості та кількісного домінування мікрофлори перитонеального ексудату після моделювання гострого поширеного перитоніту на тлі злоякісного новоутворення товстої кишки, у різні терміни спостереження, абс.

\begin{tabular}{|c|c|c|c|c|c|c|c|}
\hline \multirow{3}{*}{$\begin{array}{c}\text { Група } \\
\text { тварин }\end{array}$} & \multirow{3}{*}{ Мікроорганізми } & \multicolumn{6}{|c|}{ Термін після моделювання ГПП, год } \\
\hline & & \multicolumn{3}{|c|}{24} & \multicolumn{3}{|c|}{48} \\
\hline & & $\mathrm{s}$ & K3 & ККД & $\mathrm{s}$ & K3 & ККД \\
\hline \multirow{5}{*}{ 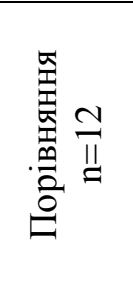 } & E. coli & 12 & 0,41 & 122,7 & 12 & 0,27 & 136,8 \\
\hline & K. pneumoniae & 4 & 0,32 & 32,2 & 7 & 0,22 & 63,1 \\
\hline & м/о роду Proteus & 4 & 0,27 & 26,8 & 6 & 0,18 & 45,5 \\
\hline & м/о роду Streptococcus & - & - & - & 3 & 0,17 & 21,5 \\
\hline & Др. гриби роду Candida & - & - & - & 3 & 0,16 & 19,5 \\
\hline \multirow{6}{*}{ 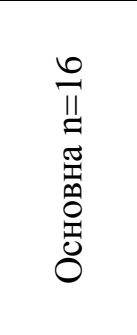 } & E. coli & 16 & 0,32 & 127,0 & 16 & 0,23 & 140,2 \\
\hline & K. pneumoniae & 7 & 0,26 & 45,3 & 12 & 0,18 & 81,9 \\
\hline & м/о роду Proteus & 8 & 0,23 & 45,8 & 13 & 0,16 & 78,7 \\
\hline & м/о роду Streptococcus & 4 & 0,19 & 19,5 & 8 & 0,15 & 45,2 \\
\hline & S. aureus & - & - & - & 5 & 0,13 & 24,2 \\
\hline & Др. гриби роду Candida & - & - & - & 9 & 0,14 & 48,5 \\
\hline
\end{tabular}

Примітки:

1. n - кількість спостережень; 2. м/о - мікроорганізми; 3. s - кількість висіяних штамів; 4. К3 - коефіцієнт значущості; 5. ККД - коефіцієнт кількісного домінування

Підсумовуючи результати проведеного дослідження, слід зазначити, що розвиток ГПП на тлі раку ТК упродовж 48 годин характеризується вірогідним збільшенням кількості висіяних штамів K. pneumoniae, мікроорганізмів роду Proteus, дpiжджоподібних грибів роду Candida, появою росту S. aureus, а також зростанням популяційного рівня E. coli, K. pneumoniae, мікроорганізмів роду Proteus та Streptococcus, дріжджоподібних грибів роду Candida. Це необхідно враховувати при виборі частоти санацій черевної порожнини, методів її проведення, а також спектра антибактеріальних препаратів.

Висновок. Створений гострий поширений перитоніт на тлі раку товстої кишки впродовж 48 годин характеризується вірогідним збільшенням кількості висіяних штамів К. pneumoniae, мікроорганізмів роду Proteus, дріжджоподібних грибів роду Candida, появою росту S. aureus, а також зростанням популяційного рівня $\mathrm{E}$. coli, K. pneumoniae, м/о роду Proteus та Streptococcus, дріжджоподібних грибів роду Candida.

Перспективи подальших досліджень. У подальшому вважаємо за доцільне дослідити в експерименті особливості фібринолітичної та протеолітичної активності очеревини та периферійної крові за умов гострого поширеного перитоніту на тлі раку товстої кишки.

\section{Список використаної літератури}

1. Поширений гнійний перитоніт: монографія / В.В. Бойко, І.А. Криворучко, С.М. Тесленко, А.В. Сивожелізов. - Х.: Прапор, 2008. - 280 с. 2. Сучасні аспекти патогенезу, діагностики, хірургічного лікування перитоніту / Ю.Б. Куцик, В.П. Федоренко, Ю.І. Шаваров [та ін.] // Укр. ж. хірург. - 2009. - № 4. - С. 92-97. 3. Бойко В.В. Попередження розвитку ускладнень при лікуванні поширених форм перитоніту / В.В. Бойко, В.К. Логачов, М.Е. Тимченко // Харківська хірург. школа. - 2011. - № 1. - С. 99-101. 4. Результаты и перспективы лечения распространенных форм перитонита / А.Г. Кригер, Б.К. Шуркалин, В.А. Горский [и др.] // Хирург. - 2001. - № 8. - С. 8-12. 5. Матвійчук Б.О. Очінка ризику розвитку гнійно-септичних ускладнень у невідкладній хірургї тонкої та товстої кишок / О.Б. Матвійчук, А.Б. Зіменковський // Укр. ж. хірург. - 2009. - № 2. - С. 95-98. 6. Василик В.М. Моделювання калового перитоніту у білих шурів / В.М. Василик // Вісн. пробл. біолог. і мед. - 2006. - Вип. 2. - C. 417-418. 7. Моделювання раку товстої кишки / І.Я. Гушул, І.О. Іващук, І.С. Давиденко [та ін.] // Клін. та експериментал. патолог. - 2015. - Т. ХІV, № 1(51). - C. 44-46. 


\section{МИКРОБИОЛОГИЧЕСКИЕ ОСОБЕННО- СТИ ПРОТЕКАНИЯ ОСТРОГО РАСПРО- СТРАНЕННОГО ПЕРИТОНИТА НА ФОНЕ РАКА ТОЛСТОЙ КИШКИ}

Резюме. В статье представлены результаты исследования качественного и количественного состава микрофлоры перитонеального экссудата после моделирования острого распространенного перитонита на фоне предварительно созданного рака толстой кишки. Установлено, что создание острого распространенного перитонита на фоне рака толстой кишки на протяжении 48 часов характеризуется достоверным увеличением количества высеянных штаммов К. pneumoniae, микроорганизмов рода Proteus (P. vulgaris, P. mirabilis, P. morganii), дрожжеподобных грибов рода Candida, появлением роста S. aureus, а также возрастанием популяционного уровня E. coli, K. pneumoniae, микроорганизмов рода Proteus и Streptococcus, дрожжеподобных грибов рода Candida. Это необходимо учитывать при выборе частоты санаций брюшной полости и методов ее проведения.

Ключевые слова: острый распространенный перитонит, рак толстой кишки, перитонеальный экссудат.

\section{MICROBIOLOGICAL PECULIARITIES OF THE CLINICAL COURSE OF ACUTE DIF- FUSE PERITONITIS AGAINST THE GROUND OF COLON CANCER}

Abstract. The results oft investigation of qualitative and quantitative composition of peritoneal exudates microflora after modeling acute diffuse peritonitis against the ground of colon cancer simulated previously are presented in the article. It has been determined that making acute diffuse peritonitis against the ground of colon cancer during 48 hours is characterized by a reliable increase of the number of cultured strains of K. pneumoniae, Proteus microorganisms (P. vulgaris, P. mirabilis, P. morganii), Candida genus, $S$. aureus growth, increase of a number of colonies of E. coli, K. pneumoniae, Proteus and Streptococcus microorganisms, Candida fungi as well. This must be considered when choosing the frequency of abdominal cavity sanation and the methods of its conduction.

Key words: acute diffuse peritonitis, colon cancer, peritoneal exudates.

Bukovinian State Medical University (Chernivtsi)

Надійшла 22.04.2015 p. Рецензент - проф. Сидорчук Р.І. (Чернівці) 